\section{'Tifway' Bermudagrass Responses to Plant Growth Regulator Application Dates}

\author{
B.J. Johnson ${ }^{1}$ \\ Department of Agronomy, University of Georgia, Georgia Station, \\ Griffin, GA 30223-1797
}

Additional index words. turfgrass injury, vegetative suppression, flurprimidol, mefluidide, paclobutrazol

Abstract. A field experiment was conducted over 2 years to determine the effects of treatment dates with plant growth regulators (PGRs) on performance of 'Tifway' bermudagrass [Cynodon transvaalensis Burtt-Davy] $\times$ [C. dactylon (L.) Pers. ]. For flurprimidol at $0.84 \mathrm{~kg} \cdot \mathrm{ha}^{-1}$, the highest injury occurred from 16 or 28 June application in 1987 and from 17 May or June application in 1988. The injury was similar from treatment dates with flurprimidol + mefluidide or paclobutrazol + mefluidide. The PGRs were applied over a longer period in 1987 than 1988 without affecting vegetative suppression of 'Tifway' bermudagrass. However, in 1988, the suppression from the 17 May treatment was equal to or better than that obtained when treatment dates were delayed until 1 June or later. Chemical names: $\alpha-(1$-methylethyl)- $\alpha$-[4-(trifluoromethoxy)phenyl]-5-pyrimidinemethanol (flurprimidol); $N$-[2,4-dimethyl-5-[[(trifluoromethyl)sulfonyl]amino]phenyl]acetamide (mefluidide); ( \pm )-( $\left.\mathrm{R}^{*} \mathrm{R}^{*}\right) \beta-[(4$-chlorophenyl)methyl]- $\alpha$-(1,1-dimethylethyl)- $1 H$-1,2,4-triazole- 1-ethanol (paclobutrazol).

Plant growth regulators (PGRs) are of interest for their potential to reduce the cost of turf maintenance. Batten (1983) reported as much as $50 \%$ reduction in mowing during 5 to 8 weeks. However, the use of PGRs on turfgrasses has two potential problems-they can cause severe injury to the turfgrass or fail to perform consistently (Christians, 1985).

Plant growth regulators are used to reduce vegetative growth and suppress seedheads, thereby reducing the number of mowings. Reducing frequency of mowing may be important on hazardous slopes (Batten, 1983) or during periods of rapid growth (Kaufmann, 1985). Although vegetative growth of bermudagrass has been reduced by PGRs (DiPaola et al., 1985; Johnson, 1988, 1989a; Rogers et al., 1987), it is important to apply the chemicals at a time that will provide the longest retardation without undesirable turfgrass injury. Kaufmann (1985) reported that the preferred time to apply a PGR to a turfgrass is just before the peak growth period. For cool-season grass, this is in the spring just before $50 \%$ of total annual growth can occur during six weeks (Kaufmann, 1985). In Georgia (Johnson, 1989b), PGRs applied 1 Mar. suppressed vegetative growth of tall fescue (Festuca arundinacea Schreb. 'Ky 31') for 6 weeks as well as or better than when PGRs were applied in mid-March or April.

Plant growth regulators applied in late May to common bermudagrass in Arkansas (Rog-

Received for publication 19 Jan. 1989. Supported by state and Hatch Act funds allocated to the Georgia Agr. Expt. Stas. The cost of publishing this paper was defrayed in part by the payment of page charges. Under postal regulations, this paper therefore must be hereby marked advertisement solely to indicate this fact.

${ }^{1}$ Professor, ers et al., 1987) had more dramatic effect on the grass than when applied in July. Similar results were also obtained from flurprimidol on 'Tifway' bermudagrass in Georgia (Johnson, 1988). Improved bermudagrasses exhibit a much different seasonal growth cycle than cool-season grasses, and much less has been published on warm-season grass responses to PGRs applied for maximum vegetation suppression. Therefore, an experiment was initiated on 'Tifway' bermudagrass to determine the effects of PGR treatment date on injury, turf density, and vegetative growth of turfgrass maintained for a high quality level.

The experiment was conducted on mature 'Tifway' bermudagrass at Griffin, Ga. The PGRs were flurprimidol at $0.84 \mathrm{~kg} \cdot \mathrm{ha}^{-1}$, flurprimidol + mefluidide at $0.84+0.14$ $\mathrm{kg} \cdot \mathrm{ha}^{-1}$, and paclobutrazol + mefluidide at $1.1+0.14 \mathrm{~kg} \cdot \mathrm{ha}^{-1}$. An untreated control was included. Treatment dates were 17 May, and 1,16 , and 28 June \pm 1 day in 1987 and 1988. All PGRs were applied to different plots each year as a broadcast spray in 375 liters of water/ha.

'Tifway' bermudagrass was fertilized uniformly $\left(\mathrm{kg} \cdot \mathrm{ha}^{-1}\right)$ with $50 \mathrm{~N}-22 \mathrm{P}-42 \mathrm{~K}$ in midApril. Additional $\mathrm{N}$ was applied at $50 \mathrm{~kg} \cdot \mathrm{ha}^{-1}$ on the day of each PGR treatment and 25 $\mathrm{kg} \cdot \mathrm{ha}^{-1}$ were applied to the same plots 4 weeks later.

The soil type was an Appling loamy sand (clayey, kaolinitic, Thermic Typic Hapludult) with $2.2 \%$ organic matter, $79 \%$ sand, $14 \%$ silt, and $7 \%$ clay. Soil $\mathrm{pH}$ was 5.7 . A soil test indicated that $\mathrm{P}$ was high (48 $\left.\mathrm{mg} \cdot \mathrm{kg}^{-1}\right)$ and $\mathrm{K}$ was low $\left(59 \mathrm{mg} \cdot \mathrm{kg}^{-1}\right)$.

'Tifway' bermudagrass was irrigated as needed to maintain optimum growth conditions before and after PGR treatments. Mowing was with a reel mower and clippings were removed before PGR treatments were applied. One half of each plot was mowed weekly at $4 \mathrm{~cm}$ throughout the study.

Bermudagrass injury and turf density were estimated visually, while heights were measured from the soil surface to tip of the newest leaf. Turf injury symptoms from PGR treatments ranged from light green to leaf tip necrosis. The ratings were based on $0 \%=$ no injury to $100 \%=$ completely brown. Rating were weekly for 8 weeks beginning 1 week after PGR treatment. Turf injury $\geq 30 \%$ was considered to be commercially unacceptable. Turf density was based on 1 $=$ no grass to $10=$ complete, uniform cover . Plant heights were measured from 2 to 8 weeks in mowed plots and in unmowed plots at 4,6 , and 8 weeks after PGR treatments. Five foliar height measurements were made per replicated plot and reported as percent suppression.

The experimental design was a split-plot with four replications. Treatments dates were randomized within blocks as whole plots and PGR treatments were randomized as splitplots. Individual plots were $1.5 \times 1.5 \mathrm{~m}$. Analysis of variance using the statistical analysis system (General Linear Model procedure of SAS) was conducted within and across years (SAS Institute, 1982). The data was presented by year because of significant year $\times$ PGR $\times$ date interactions. When PGR $x$ treatment date interaction occurred, treatment date comparisons were made within each PGR treatment.

The injury of 'Tifway' bermudagrass to PGRs varied between years and was influenced, in part, by treatment date (Table 1). In 1987, 3 weeks after flurprimidol was applied alone on 16 or 28 June, 'Tifway' bermudagrass was injured more than when applied 17 May or 1 June. By 5 weeks, the turfgrass treated with flurprimidol on 16 June had recovered slower than when treated 28 June. There were no differences due to treatment date when ratings were made 7 or 8 weeks after PGR treatment.

In 1988, flurprimidol applied 17 May or 1 June injured 'Tifway' bermudagrass more than when applied 16 June or later when ratings were made 5 weeks after treatment (Table 1). The grass treated 17 May with the PGR did not fully recover when final ratings were made 8 weeks after treatment.

There was little difference in turfgrass injury from treatment date of flurprimidol + mefluidide or paclobutrazol + mefluidide in 1987 (Table 1). However, in 1988, both tankmixed treatments injured bermudagrass most when applied before 28 June, as indicated by ratings made 3 weeks after treatment. Turf treated with paclobutrazol + mefluidide on 17 May did not recover until 8 weeks after treatment, while turf treated with flurprimidol + mefluidide at the same date had not fully recovered at that time. Recovery was more rapid for later treatments.

The basis for the difference in response between years to treatment date is not known. During May, June, and July, the rainfall in 1987 was $150 \mathrm{~mm}$ more than in 1988 , but the turfgrass was irrigated as needed to maintain growing conditions. Although there 
Table 1. Influence of plant growth regulator application dates on 'Tifway' bermudagrass injury following various periods of growth."

\begin{tabular}{|c|c|c|c|c|c|c|c|}
\hline \multirow[b]{3}{*}{$\begin{array}{l}\text { Application } \\
\text { dates }\end{array}$} & \multicolumn{7}{|c|}{ Turfgrass injury $(\%)^{y}$} \\
\hline & \multicolumn{3}{|c|}{1987} & \multicolumn{4}{|c|}{1988} \\
\hline & Flurprimidol & $\begin{array}{c}\text { Flurprimidol } \\
+ \\
\text { mefluidide }\end{array}$ & $\begin{array}{c}\text { Paclobutrazol } \\
+ \\
\text { mefluidide }\end{array}$ & Flurprimidol & $\begin{array}{c}\text { Flurprimidol } \\
+ \\
\text { mefluidide }\end{array}$ & & $\begin{array}{c}\text { Paclobutrazol } \\
+ \\
\text { mefluidide } \\
\end{array}$ \\
\hline \multicolumn{8}{|c|}{3 weeks } \\
\hline 17 May & 16 & 16 & 14 & 18 & 17 & & 19 \\
\hline 1 June & 12 & 6 & 7 & 27 & 27 & & 23 \\
\hline 16 June & 23 & 19 & 19 & 18 & 22 & & 20 \\
\hline 28 June & 24 & 24 & 17 & 10 & 5 & & 8 \\
\hline LSD 0.05 & 6 & 6 & NS & 10 & 11 & & 9 \\
\hline \multicolumn{8}{|c|}{5 weeks } \\
\hline 17 May & 17 & 16 & 8 & 30 & 25 & & 25 \\
\hline 1 June & 7 & 6 & 7 & 33 & 23 & & 16 \\
\hline 16 June & 28 & 18 & 23 & 12 & 13 & & 17 \\
\hline 28 June & 14 & 15 & 13 & 12 & 9 & & 5 \\
\hline LSD 0.05 & 10 & NS & NS & 8 & 12 & & 10 \\
\hline \multicolumn{8}{|c|}{7 weeks } \\
\hline $17 \mathrm{May}$ & 12 & 11 & 0 & 23 & 20 & $\cdots$ & 12 \\
\hline 1 June & 8 & 0 & 0 & 8 & 0 & & 0 \\
\hline 16 June & 14 & 10 & 13 & 0 & 0 & & 4 \\
\hline 28 June & 5 & 9 & 9 & 0 & 0 & & 0 \\
\hline LSD 0.05 & NS & NS & NS & 5 & 8 & & 7 \\
\hline \multicolumn{8}{|c|}{8 weeks } \\
\hline 17 May & 2 & 4 & 0 & 13 & 10 & & 3 \\
\hline 1 June & 8 & 3 & 5 & 0 & 0 & & 0 \\
\hline 16 June & 11 & 3 & 9 & 0 & 0 & & 5 \\
\hline 28 June & 5 & 8 & 8 & 0 & 0 & & 0 \\
\hline LSD 0.05 & NS & NS & NS & 7 & 3 & & NS \\
\hline
\end{tabular}

zPlant growth regulator rates $\left(\mathrm{kg} \cdot \mathrm{ha}^{-1}\right)$ were: flurprimidol, 0.84 ; flurprimidol + mefluidide, $0.84+0.14 ;$ and paclobutrazol + mefluidide, $1.1+0.14$. y Turf injury ratings are means from four replications and based on $0 \%=$ no injury and $100 \%=$ complete kill. Injury $\geq 30 \%$ was considered unacceptable.

Table 2. Influence of plant growth regulator treatment application dates on turf density of 'Tifway' bermudagrass. ${ }^{2}$

\begin{tabular}{|c|c|c|c|c|c|c|}
\hline \multirow[b]{3}{*}{$\begin{array}{l}\text { Application } \\
\text { dates }\end{array}$} & \multicolumn{6}{|c|}{ Turf density (1 to 10$)^{\mathrm{y}}$} \\
\hline & \multicolumn{3}{|c|}{1987} & \multicolumn{3}{|c|}{1988} \\
\hline & Flurprimidol & $\begin{array}{c}\text { Flurprimidol } \\
+ \\
\text { mefluidide }\end{array}$ & $\begin{array}{c}\text { Paclobutrazol } \\
+ \\
\text { mefluidide }\end{array}$ & Flurprimidol & $\begin{array}{c}\text { Flurprimidol } \\
+ \\
\text { mefluidide }\end{array}$ & $\begin{array}{c}\text { Paclobutrazol } \\
+ \\
\text { mefluidide }\end{array}$ \\
\hline 17. May & 8.9 & 9.3 & 9.6 & 8.5 & 8.2 & 9.2 \\
\hline 1 June & 8.9 & 9.4 & 9.4 & 8.8 & 9.5 & 9.3 \\
\hline 16 June & 7.9 & 8.5 & 7.8 & 9.4 & 9.5 & 9.1 \\
\hline 28 June & 9.1 & 8.8 & 8.9 & 9.5 & 9.8 & 9.8 \\
\hline LSD 0.05 & NS & NS & 1.4 & 0.5 & 0.3 & 0.4 \\
\hline
\end{tabular}

zPlant growth regulator rates $\left(\mathrm{kg} \cdot \mathrm{ha}^{-1}\right)$ were: flurprimidol, $0.84 ;$ flurprimidol + mefluidide, $0.84+0.14 ;$ and paclobutrazol + mefluidide, $1.1+0.14$. y Turf density ratings are means from four replications, were made 7 weeks after treatment, and are based on $1=$ no turf and $10=$ complete, uniform turf cover.

was some difference in temperature for 2 weeks after PGR treatment, it was not consistent.

The density of 'Tifway' bermudagrass was influenced by PGR treatment date at 7 weeks after treatment (Table 2). Turf density following paclobutrazol + mefluidide treatment on 16 June 1987 was lower than when the same treatment was applied 17 May or 1 June. At the same time in 1988, turf density following treatment with flurprimidol on 17 May or 1 June, flurprimidol + mefluidide on 17 May, or paclobutrazol + mefluidide on 17 May, 1, or 16 June was lower than when each respective PGR treatment was applied at other dates. However, the lower density of turf treated with PGRs was temporary, as the turf recovered when final ratings were made 8 weeks after treatment (data not presented).

In 1987, vegetative suppression of mowed 'Tifway' bermudagrass 2 weeks after the 28
June treatment with flurprimidol + mefluidide was higher than when treated 17 May (Table 3). Although there was no difference in vegetation suppression 2 and 3 weeks after the 16 and 29 June treatments, at 5 weeks, turf treated 16 June was suppressed more than turf treated 28 June. During 1987, paclobutrazol + mefluidide was only slightly influenced by treatment date (evaluated after 5 weeks), while vegetative suppression with flurprimidol was not influenced by treatment date.

The vegetative suppression of mowed 'Tifway' bermudagrass in 1988 was as high or higher and over a longer period from the 17 May treatment with flurprimidol than with later treatment dates. Although there was no difference in suppression of turfgrass from treatment dates with tank mixes of mefluidide with flurprimidol or paclobutrazol at 2 or 3 weeks after treatments, bermudagrass was suppressed longer when treated 17 May than when treated anytime in June.

These results show that PGRs could have been applied over a longer period in 1987 than 1988 without affecting the suppression of vegetative growth of mowed 'Tifway' bermudagrass. However, in 1988, turfgrass suppression was as good or better from the 17 May treatment as from delayed treatments in June.

Flurprimidol applied alone resulted in vegetative growth only 1,2 to $2.9 \mathrm{~cm}$ high in unmowed 'Tifway' bermudagrass in 1987. In 1988, the height ranged from $4 \mathrm{~cm}$ when flurprimidol was applied 17 May to $8.4 \mathrm{~cm}$ when applied 16 June. Treatment date did not influence the performance of flurprimidol in 1987 as it did in 1988 when final ratings were made 8 weeks after treatment (Table 4). There was no advantage with tank mixes of flurprimidol + mefluidide or paclobutrazol + mefluidide in suppressing the vegetative height of unmowed 'Tifway' ber- 
'Table 3. Influence of plant growth regulator treatment application dates on vegetative height of mowed 'Tifway' bermudagrass following various periods of growth. ${ }^{2}$

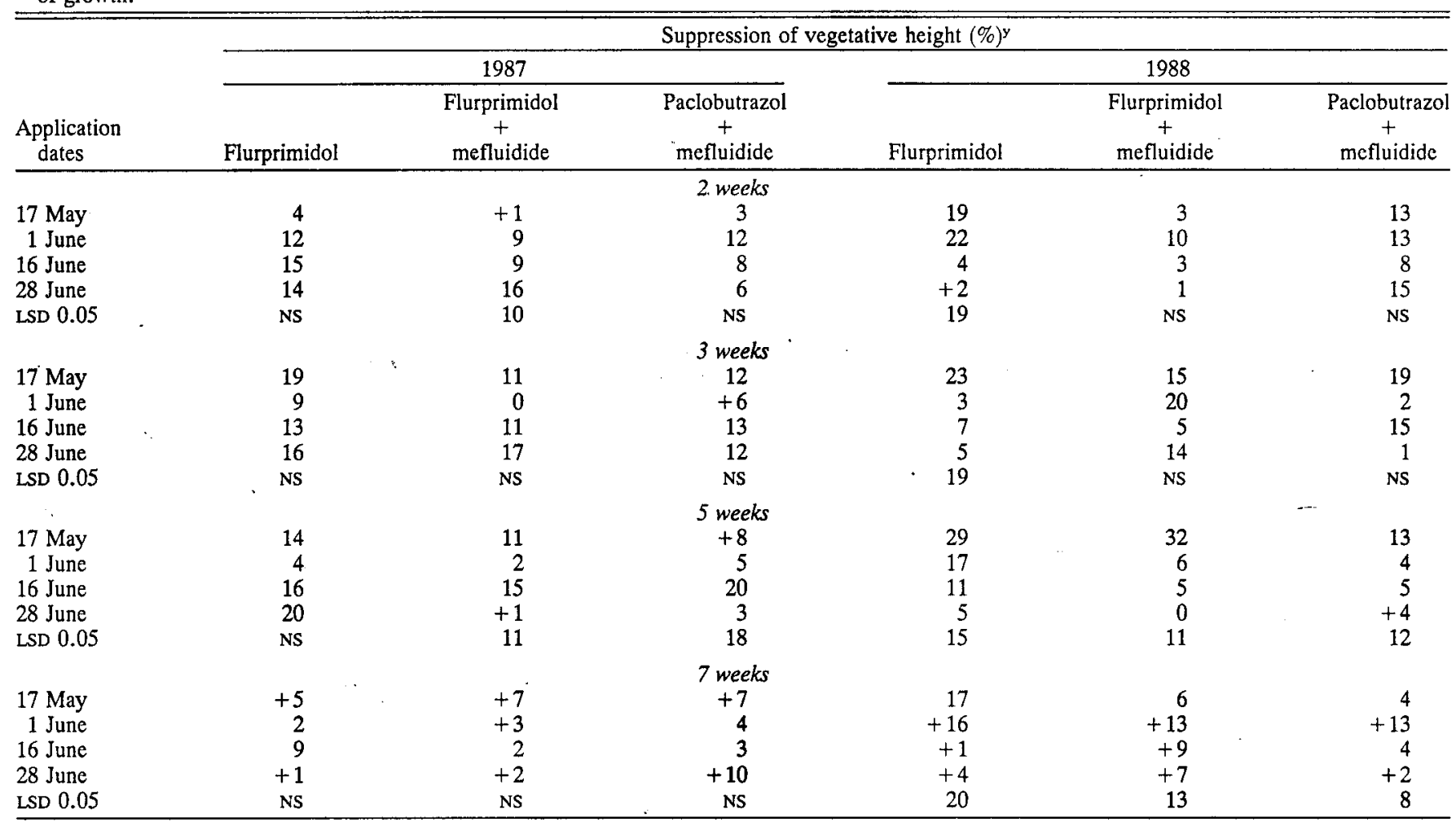

zPlant growth regulator rates $\left(\mathrm{kg} \cdot \mathrm{ha}^{-1}\right)$ were: flurprimidol, 0.84 ; flurprimidol + mefluidide, $0.84+0.14$; and paclobutrazol + mefluidide, $1.1+0.14$. ${ }^{\mathrm{r}}$ Vegetative height ratings are means from four replications and based on percent suppression. Values preceded by + are taller than untreated plants.

Table 4. Influence of plant growth regulator treatment application dates on vegetative height of unmowed 'Tifway' bermudagrass 8 weeks after treatment. ${ }^{z}$

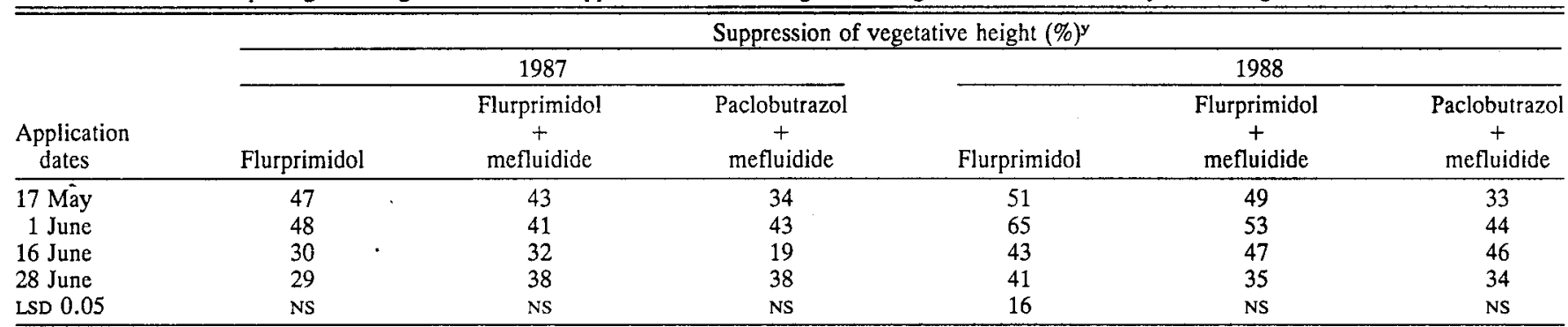

zPlant growth regulator rates $\left(\mathrm{kg} \cdot \mathrm{ha}^{-1}\right)$ were: flurprimidol, 0.84 ; flurprimidol + mefluidide, $0.84+0.14$; and paclobutrazol + mefluidide, $1.1+0.14$. y Vegetative height ratings were made 8 weeks after treatment, are means from four replications, and are based on percent suppression.

mudagrass compared with flurprimidol applied alone.

These results show that either flurprimidol, flurprimidol + mefluidide, or paclobutrazol + mefluidide will cause slight to severe injury to 'Tifway' bermudagrass, but that the turfgrass recovered to an acceptable level on or before 7 weeks after treatment. There was either little or no difference in vegetative growth of mowed bermudagrass due to PGR treatment dates in 1987. However, in 1988, the suppression of growth was as good or better when PGRs were applied mid-May than when delayed until 1 June or later.

\section{Literature Cited}

Batten, S.M. 1983. Growth regulators-New tools for the '80's. USGA Green Section 21(3):1-3.

Christians, N.E. 1985. Response of Kentucky bluegrass to four growth retardants. J. Amer. Soc. Hort. Sci. 110:765-769.

Di Paola, J.M., W.B. Gilbert, and W.M. Lewis 1985. Turfgrass response to growth retardants. Fact Sheet Florida Turf Dig. 2(1).

Johnson, B.J. 1988. Influence of nitrogen in the response of 'Tifway' bermudagrass (Cynodon dactylon) to flurprimidol. Weed Technol. 2:5558.

Johnson, B.J. 1989a. Response of bermudagrasses (Cynodon spp.) to plant growth regulators. Weed Technol. 3:440-444.
Johnson, B.J. 1989b. Response of tall fescue (Festuca arundinacea) to plant growth regulator application dates. Weed Technol. 3:408-413.

Kaufmann, J.E. 1985. A common sense approach to the use of PGRs. Proc. Missouri Lawn and Turf Conf. 69-86.

Rogers, J.N., III., E.M. Miller, and J.W. King. 1987. Growth retardation of bermudagrass with metsulfuron methyl and sulfometuron methyl. Agron. J. 79:225-229.

SAS Institute, Inc. 1982. SAS users guide. SAS Institute, Inc., Carey, N.C. 